\title{
The Geographical Transmission of Smallpox in the Franco-Prussian War: Prisoner of War Camps and Their Impact upon Epidemic Diffusion Processes in the Civil Settlement System of Prussia, 1870-71
}

\author{
MATTHEW SMALLMAN-RAYNOR and ANDREW D CLIFF*
}

The disease history of nineteenth-century Europe was punctuated by a series of severe-sometimes catastrophic - epidemics which spread as a consequence of war. ${ }^{1}$ In his great Handbook of geographical and historical pathology (1883), August Hirsch traced one of the last "considerable" outbreaks of bubonic plague in Europe to "1828-29, when the Russian and Turkish forces came into collision in Wallachia". Likewise, writing of Asiatic cholera in the Baltic provinces and Poland in 1830-31, Hirsch observed how the "military operations of the Russo-Polish War contributed materially to its diffusion". ${ }^{3}$ Some thirty-five years later, the epidemic of cholera which spread as a consequence of the Austro-Prussian War (1866) claimed an estimated 165,000 lives in the Austrian Crownlands, ${ }^{4}$ while the Franco-Prussian War

\footnotetext{
* Matthew Smallman-Raynor, PhD, School of Geography, University of Nottingham, University Park, Nottingham, NG7 2RD, UK. Andrew D Cliff, FBA, DSc, Department of Geography, University of Cambridge, Downing Place, Cambridge, CB2 3EN, UK
}

The work described has been undertaken as part of a five-year programme of research entitled Disease in war, 1850-1990: geographical patterns, spread and demographic impact, funded by the Leverhulme Trust. Their financial support is gratefully acknowledged. The authors also thank Jonathan Bradshaw for assistance with the translation of cited texts from the original German, and the referees for their constructive comments.

${ }^{1}$ See, for example, Frank Aker and James C Cecil, 'The influence of disease upon European history', Milit. Med., 1983, 148: 441-6; Charles
Creighton, $A$ history of epidemics in Britain, volume II: From the extinction of the plague to the present time, 2nd ed., London, Frank Cass, 1965; Samuel Dumas and K O Vedel-Petersen, Losses of life caused by war, Oxford, Clarendon Press, 1923; August Hirsch, Handbook of geographical and historical pathology: volume I: Acute infective diseases, London, New Sydenham Society, 1883; Henry Lancaster, Expectations of life: a study in the demography, statistics, and history of world mortality, New York and London, Springer, 1990, pp. 314-40; Ralph Major, War and disease, London, Hutchinson, 1940; Friedrich Prinzing, Epidemics resulting from wars, Oxford, Clarendon Press, 1916.

${ }^{2}$ Hirsch, op. cit., note 1 above, pp. 503-4. For further details, see Prinzing, op. cit., note 1 above, pp. 165-70.

${ }^{3}$ Hirsch, op. cit., note 1 above, p. 398.

${ }^{4}$ Prinzing, op. cit., note 1 above, p. 186. 


\section{Matthew Smallman-Raynor and Andrew D Cliff}

(1870-71) sparked an epidemic of smallpox which left some 500,000 soldiers and civilians dead throughout Europe. ${ }^{5}$

The factors that contributed to the epidemiological risk of war in nineteenthcentury Europe are well known, and include a broad range of social, biological and environmental considerations. ${ }^{6}$ As with conflicts in other historical periods, mobilization heightened mixing of both military and civil populations, thereby increasing the likelihood of disease transmission. Frequently, military personnel were drawn from a variety of epidemiological backgrounds, they were assembled and deployed in environments to which they were not acclimatized, and they carried infections for which the civil inhabitants of the war zones had little or no acquired immunity. For all involved, resistance to infection was further compromised by mental and physical stress, trauma, nutritional deprivation and exposure to the elements. Insanitary conditions, enforced population concentration and crowding, a lack of medical provision, and the collapse of the conventional rules of social behaviour further compounded the epidemiological unhealthiness of war.

Many of these factors were manifested on the soil of France and the allied states of Germany during the Franco-Prussian War of 1870-71. From the order for the mobilization of France against Prussia on 14 July 1870, to the agreement of an armistice between France and the newly-formed German Empire on 28 January 1871 , almost three million troops were deployed by the warring states. ${ }^{7}$ Severe outbreaks of typhoid fever and dysentery-amongst a host of infectious diseaseswere to debilitate the troops on both sides. ${ }^{8}$ But these outbreaks were dwarfed by an epidemic of smallpox that ripped through the military and civil populations of France and the allied states of Germany. ${ }^{9}$ The dimensions of the resulting mortality can be seen in Table 1. All told, some 300,000 inhabitants of France, Prussia and the smaller German states are believed to have succumbed to smallpox during the war period and its immediate aftermath; countless others were permanently disfigured by the disease. ${ }^{10}$

As part of an ongoing project concerned with the historical geography of warrelated epidemics, we have examined the impact of a series of wars-Cuban Insurrection (1895-98), Spanish-American War (1898) and Philippine-American War (1899-1902) _ on the spatial propagation of such infectious diseases as cholera,

\footnotetext{
${ }^{5}$ Prinzing, op. cit., note 1 above, pp. 197-285; $R$ Bruce Low, 'The incidence of small-pox throughout the world in recent years', Reports of the Local Government Board on public health and medical subjects, New Series, 1918, 17: 3-4; J D Rolleston, 'The smallpox pandemic of 1870-74', Proc. $R$. Soc. Med., Section of Epidemiology and State Medicine, 1933, 27: 177-92; Frank Fenner, Donald Henderson, Isao Arita, Zdenek Ježek, and Ivan Ladnyi, Smallpox and its eradication, Geneva, World Health Organization, 1988, p. 232.

${ }^{6}$ See, for example, Hirsch, op. cit., note 1 above; Prinzing, op. cit., note 1 above; Major,
}

op. cit., note 1 above; Lancaster, op. cit., note 1 above; Richard Garfield and Alfred Neugut, 'Epidemiologic analysis of warfare: a historical review', J. Am. med. Ass., 1991, 266: 688-92; Barry Levy and Victor Sidel (eds), War and public health, New York, Oxford University Press, 1997.

${ }^{7}$ Prinzing, op. cit., note 1 above, p. 189;

Dumas and Vedel-Petersen, op. cit., note 1 above, pp. 51-3.

${ }^{8}$ Prinzing, op. cit., note 1 above, pp. 189-97.

${ }^{9}$ See Fenner, et al., op. cit., note 5 above, p. 232. 284. 


\section{Geographical Transmission of Smallpox in the Franco-Prussian War}

Table 1

Deaths from smallpox in the military and civilian populations of France and Germany, 1870-71

\begin{tabular}{lcc}
\hline Country & $\begin{array}{c}\text { Population size } \\
\text { (millions) }\end{array}$ & $\begin{array}{c}\text { Smallpox } \\
\text { deaths }\end{array}$ \\
\hline France & & \\
$\quad$ Soldiers & $1.50^{2}$ & $25,077(167.18)$ \\
Civilians & $36.01^{3}$ & $89,954(24.98)$ \\
Germany & & \\
$\quad$ Soldiers & $1.49^{2}$ & $297(1.99)$ \\
Civilians & $41.06^{4}$ & $176,977(43.10)^{5}$ \\
\hline
\end{tabular}

${ }^{1}$ Death rates per 10,000 in parentheses.

${ }^{2}$ Estimated total number deployed.

${ }^{3} 1872$ census.

${ }^{4} 1871$ census.

${ }^{5}$ Mortality for $1870-72$.

Sources: Friedrich Prinzing, Epidemics resulting from wars, Oxford, Clarendon Press, 1916; Samuel Dumas and K O Vedel-Petersen, Losses of life caused by war, Oxford, Clarendon Press, 1923; Brian R Mitchell, International historical statistics: Europe, 1750-1993, 4th ed., Basingstoke, Macmillan, 1998.

enteric/typhoid fever, smallpox and yellow fever. ${ }^{11}$ In this paper, we extend our geographical concerns to an examination of the processes by which smallpox spread, or diffused, in one combatant state (Prussia) during the Franco-Prussian War of 1870-71. To this end, we draw on the statistical information included in an historic survey of smallpox in wartime Prussia: 'Die Pocken-Epidemie in Preussen', prepared by Albert Guttstadt and published in $1873 .^{12}$

Socio-medical aspects of the smallpox epidemic in wartime Prussia, including the role of the epidemic as a spur to the introduction of compulsory vaccination and revaccination under the German Imperial Vaccination Law of 1874, have been

\footnotetext{
${ }^{11}$ See, for example, Matthew Smallman-Raynor and Andrew Cliff, 'The Philippines insurrection and the 1902-4 cholera epidemic: part I.

Epidemiological diffusion processes in war', $J$. Hist. Geog., 1998, 24: 69-89; idem, 'The Philippines insurrection and the 1902-4 cholera epidemic: part II. Diffusion patterns in war and peace', J. Hist. Geog., 1998, 24: 188-210; idem, 'The spatial dynamics of epidemics in war and peace: Cuba and the insurrection against Spain', Trans. Inst. Br.
}

Geographers, 1999, 24: 331-52; idem, 'Epidemic diffusion processes in a system of US military camps: transfer diffusion and the spread of typhoid fever in the Spanish-American War, 1898', Ann. Ass. Am. Geographers, 2001, 91: 71-91.

${ }^{12}$ Albert Guttstadt, 'Die Pocken-Epidemie in Preussen, insbesondere in Berlin 1870/72, nebst Beiträgen zur Beurtheilung der Impffrage', Zeitschrift des königlich Preussischen Statistischen Bureaus, 1873, 13: 116-58. 


\section{Matthew Smallman-Raynor and Andrew D Cliff}

studied. ${ }^{13}$ Our analysis of the Franco-Prussian War is underpinned by a fundamental geographical issue in the historical association of war and disease: how do military populations affect the processes by which an infectious disease spreads in a civil settlement system? The paper begins with a brief outline of the war, the clinical and epidemiological characteristics of smallpox, and the factors that shaped the spread of the disease in Prussia. We then outline the nature of the disease data contained in Guttstadt's article. A number of statistical methods have been developed for the identification of disease diffusion processes ${ }^{14}$ and, in the third part of the paper, one such technique (multiple regression analysis) is introduced to analyse the spread of smallpox in two functionally discrete, but geographically concordant, settlement systems of Prussia: (i) the military system of prisoner of war (POW) camps and other POW-related facilities; and (ii) the civil system of urban centres.

For the war period, the analysis demonstrates that the expansion of smallpox in the civil population of Prussia was underpinned by a diffusion process that involved both geographically-localized spread (contagious diffusion), and spread from large to small centres (hierarchical diffusion). Crucially, however, this process was detached from the arrangement of settlements in the urban system. Rather, spread was conditioned by the temporary and makeshift system of POW camps which, during the course of the war, had been established in the vicinity of many urban centres. The findings, which are consistent with evidence for the role of French prisoners in the rapid and widespread seeding of the epidemic in Prussia, ${ }^{15}$ underscore how military populations may influence the propagation of epidemic diseases in civil settlement systems. Additionally, the results highlight the historical importance of inter-linked networks of institutions, such as POW camps, not only in the localized amplification of smallpox outbreaks, but also in the spatial structuring of state-wide epidemics.

\section{Background to the Epidemic}

\section{The Study Site}

Figure 1 shows the state boundaries of Prussia on the eve of the Franco-Prussian War. As the principal member of the North German Confederation, Prussia occupied approximately $300,000 \mathrm{~km}^{2}$ of continental Europe, extending from France, Belgium and Holland in the west to the Baltic Sea and Poland in the east. According to the post-war census of 1871 , the population of Prussia numbered 24.7 millions. ${ }^{16}$ The

\footnotetext{
${ }^{13}$ See, for example, Prinzing , op. cit., note 1 above, pp. 282-5; Claudia Huerkamp, 'The history of smallpox vaccination in Germany: a first step in the medicalization of the general public', J. Contemp. Hist., 1985, 20: 617-35; Peter Hennock, 'Vaccination policy against smallpox, 1835-1914: a comparison of England with Prussia and Imperial Germany', Soc. Hist. Med., 1998, 11: 49-71.

${ }^{14}$ Methods for the identification of disease diffusion processes are described in Andrew Cliff
}

and Peter Haggett, Atlas of disease distributions: analytic approaches to epidemiological data, Oxford, Basil Blackwell, 1988.

${ }^{15}$ See, for example, Guttstadt, op. cit., note 12 above; Prinzing, op. cit., note 1 above; Rolleston, op. cit., note 5 above.

${ }^{16}$ Brian Mitchell, International historical statistics: Europe, 1750-1993, 4th ed., Basingstoke, Macmillan, 1998. 


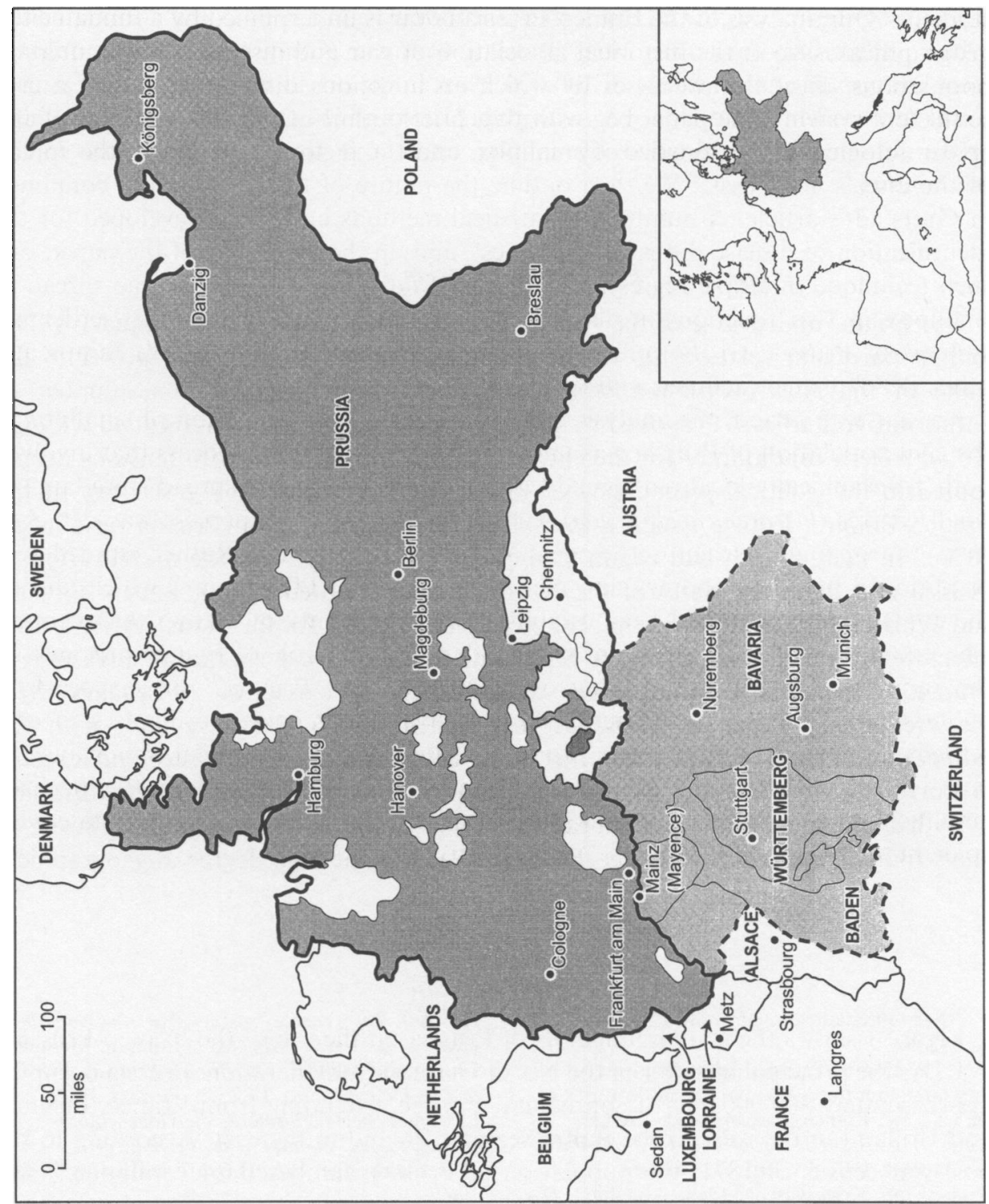

Figure 1: Location map of Prussia at the outbreak of the Franco-Prussian War, 1870. The North German Confederation comprises the area contained within the heavy solid line. Prussia is shaded with a dark tint. The South German Confederation is contained within the heavy pecked line and is shaded with a light tint. Other places referred to in the text are named. The inset map locates the study area within Europe. 


\section{Matthew Smallman-Raynor and Andrew D Cliff}

capital city, Berlin, was the largest settlement (population 826,341) and dominated the urban system; only four other cities (Breslau, Cologne, Königsberg and Magdeburg) recorded populations in excess of 100,000. Next in the urban hierarchy came Danzig, Frankfurt am Main and Hanover, with populations of about 90,000, while elsewhere urban settlement was typified by smaller cities and towns of less than 75,000 inhabitants. ${ }^{17}$

\section{The Franco-Prussian War}

The origins and course of the Franco-Prussian War (July 1870 to January 1871), and its particular relationship to the changing balance of European power in the wake of the Austro-Prussian War (1866), have been outlined in a number of authoritative studies. ${ }^{18}$ Provoked by the diplomatic machinations associated with the Hohenzollern candidature for the vacant Spanish throne, ${ }^{19}$ but with tensions deeply rooted in the political ascendancy of Prussia and its threat to the security of the French Empire, France issued a formal declaration of war on Prussia on 17 July $1870 .{ }^{20}$ In fact, France had begun to mobilize on 14 July, with the mobilization of Prussia and the other states of the North German Confederation, Baden, Bavaria and Württemberg in the days that followed (see Figure 1 for locations). After a brief offensive by the French army in Saarland, followed by a six-month invasion of France by the allied German forces, an armistice was agreed on 28 January 1871; the Preliminary Peace of Versailles was signed on 26 February and, with the ratification of the Treaty of Frankfurt on 23 May, France ceded Alsace and a sector of Lorraine (Moselle and a part of Meurthe) to the newly-formed German Empire.

With deployment of the nascent railway system at the forefront of military strategy, one striking feature of the Franco-Prussian War was the high degree of geographical

\footnotetext{
${ }^{17}$ See Guttstadt, op. cit., note 12 above, pp. $143-4$.

${ }^{18}$ The Franco-Prussian War has attracted a very large literature. For the official histories of the war, see: France, État-major de l'Armée, Section Historique, La guerre de 1870-71, Paris, R Chapelot, 1901-14; Prussia, Grosser Generalstab, Kriegsgeschichtliche Abteilung, Der Deutsch-Französische Krieg, 1870-1, Berlin, E S Mittler, 1872-81 (The Franco-German War 1870-1871, translated from the German official account by Capt. F C H Clarke, London, HMSO, 1874-1884). Accessible English-language overviews of the origin and course of the war include: William Carr, The origins of the wars of German unification, London, Longman, 1991, pp. 144-213; S William Halperin, 'The origins of the Franco-Prussian War revisited: Bismarck and the Hohenzollern candidature for the Spanish throne', J. mod. Hist., 1973, 45: 83-91; Michael
}

Howard, The Franco-Prussian War: the German invasion of France, 1870-1871, London, Methuen, 1961; Émile Ollivier, The Franco-Prussian War and its hidden causes, London, Pitman, 1913; Lawrence Steefel, Bismark, the Hohenzollern candidacy, and the origins of the Franco-German War, Cambridge, MA, Harvard University Press, 1962.

${ }^{19}$ Among the candidates for the Spanish throne, vacant after the expulsion of Queen Isabella II in 1868, was Prince Leopold of Hohenzollern, a distant relative of the Prussian King Wilhem I. Details of the resulting diplomatic crisis with France are given in: Steefel, op. cit., note 18 above; Halperin, op. cit., note 18 above.

${ }^{20}$ France had voted war credits on $15 \mathrm{July}$; the formal declaration of war was issued from Paris on 17 July and presented to the Prussian Prime Minister, Otto von Bismarck, on 19 July. 


\section{Geographical Transmission of Smallpox in the Franco-Prussian War}

mobility associated with the fighting forces. So, during the seven-month period of active hostilities, more than 1.5 million soldiers are believed to have crossed the border between France and the states of Germany. ${ }^{21}$ The majority of these were allied German troops engaged in the invasion of France. ${ }^{22}$ Pivotal to the appearance of smallpox in Prussia, however, were the large numbers of French soldiers who were transported to Prussia as POWs. Some impression of the number of French prisoners in Prussia can be gained from Table 2. For a sample of POW camps and related facilities at 56 locations, the table gives the total (maximum) prisoner population as 268,252 officers and men. Other estimates, formed to include the larger states of Germany, place the maximum number of French prisoners at almost 373,000 , while probably as many as 723,500 French soldiers (including the Paris garrison and Bourbaki's army in Switzerland) were incarcerated at some stage during the war. $^{23}$

\section{Smallpox}

Although eradicated globally by 1979 , smallpox was historically a severe and often fatal viral disease. Transmission was through direct contact with the oropharyngeal secretions of an infected person and, less commonly, by contact with the clothing or bedding of a smallpox patient. The disease took a characteristic clinical course. An incubation period of about twelve days was followed by the abrupt onset of fever, headache and muscle pain. After two to five days, a papular rash appeared on the face, palms, soles and other parts of the body. Soon thereafter, the pimples of the rash turned to pustules, eventually to form scabs which fell off three to four weeks after onset. In addition to extreme scarring, possible sequelae included blindness and male infertility. Death as a result of toxaemia and massive haemorrhaging occurred in up to 30 per cent of untreated cases. ${ }^{24}$

Nineteenth-century Europe was no stranger to the ravages of smallpox. So, despite the introduction of smallpox vaccination in many states of Europe during the early years of the century, ${ }^{25}$ continent-wide pandemics of the disease (first in 1824-29, and then in 1837-40 and 1870-74) were interspersed with more localized epidemics of greater or lesser intensity. ${ }^{26}$ Although the antecedents of these pandemic events were the subject of contemporary speculation and conjecture, ${ }^{27}$ the immediate origins of the epidemic that spread as a consequence of the Franco-Prussian War-an early

\footnotetext{
${ }^{21}$ Dumas and Vedel-Petersen, op. cit., note 1 above, p. 51; Prinzing, op. cit., note 1 above, pp. 189, 208-9.

${ }^{22}$ Dumas and Vedel-Petersen, op. cit., note 1 above, p. 51 . 208-9.

${ }^{23}$ Prinzing, op. cit., note 1 above, pp. 189 ,

${ }^{24}$ Fenner, et al., op. cit., note 5 above.
}

\footnotetext{
${ }^{25} \mathrm{See}$, for example, Hirsch, op. cit., note 1 above, p. 142; Fenner, et al., op. cit., note 5 above.

${ }^{26}$ Fenner, et al., op. cit., note 5 above, p. 231.

${ }^{27}$ See, for example, letter from W R Cornish, 'The origin of the smallpox epidemic', Lancet, 1871 , i: 703 .
} 


\section{Matthew Smallman-Raynor and Andrew D Cliff}

manifestation of the European pandemic of 1870-74 can be traced, with some degree of accuracy, to France. As early as New Year's Day 1870, an anonymous report in the Lancet warned that smallpox had appeared in Paris. ${ }^{28}$ In fact, smallpox had first surfaced in the départments of northern and southeastern France in the latter months of $1869,{ }^{29}$ with the Indian sub-continent as a postulated source of the disease.$^{30}$ But, whatever its exact origins, the epidemic continued to escalate in France and, in late May 1870, an emergency conference on smallpox control was convened in Paris. ${ }^{31}$ Two months later, with smallpox still spreading "fearfully" in the French capital,$^{32}$ France declared war on Prussia.

From its putative origins in France, smallpox was to spread in an especially severe (haemorrhagic) form in Prussia and the other states of Germany. ${ }^{33}$ However, it is evident from Table 1 that the disease did not strike the military and civil populations of the combatant states with equal severity. Low levels of vaccine-acquired immunity were to favour dissemination of the disease in (i) the large contingent of French soldiers transferred to Prussia as prisoners of war and (ii) Prussian civilians. ${ }^{34}$ In contrast, with a compulsory programme of smallpox vaccination and revaccination that dated from 1834, the Prussian army was to enjoy marked immunity to the disease. $^{35}$

\section{The Data}

To examine the spread of smallpox in Prussia during the war of 1870-71, we draw on the epidemiological information collated by a renowned medical statistician, physician and veteran of the Franco-Prussian War-Albert Guttstadt. During the course of his employment with the Prussian Statistical Office (Berlin) in the early 1870s, Guttstadt undertook a comprehensive review of reported smallpox activity in the various localities of wartime Prussia. ${ }^{36}$ The results of his historic study, gathered under the title 'Die Pocken-Epidemie in Preussen, insbesondere in Berlin 1870/72, nebst Beiträgen zur Beurtheilung der Impffrage' (The smallpox epidemic in Prussia, especially in Berlin 1870/72, together with contributions for the evaluation of the

${ }^{28}$ Lancet, 1870, i: 24.

${ }^{29}$ Rolleston, op. cit., note 5 above, pp. 178-9.

${ }^{30}$ Cornish, op. cit., note 27 above.

${ }^{31}$ Rolleston, op. cit., note 5 above, p. 179.

${ }^{32}$ Lancet, 1870, ii: 183.

${ }^{33}$ With the exception of isolated reports of smallpox in Berlin, and a more severe outbreak of the disease in the city of Chemnitz (Saxony), smallpox was all but absent from Prussia and the allied states of Germany at the start of the Franco-Prussian War. See Guttstadt, op. cit., note 12 above, pp. 130-8; Prinzing, op. cit., note 1 above, p. 199; Rolleston, op. cit., note 5 above, p. 186.

${ }^{34}$ For the French army, a programme of compulsory vaccination of all new recruits had been introduced in 1859 . However, the reputedly high failure rate of the army's (re)vaccination schedule in the years immediately preceding the war with Prussia, coupled with the failure to vaccinate those men who were enlisted after the outbreak of hostilities, ensured that a large sector of the French army was prone to smallpox. See Rolleston, op. cit., note 5 above, p. 179. For Prussian civilians, a compulsory programme of smallpox vaccination and revaccination awaited the implementation of the post-war Imperial Vaccination Law of 1874. See Prinzing, op. cit., note 1 above, p. 198.

${ }^{35}$ See Hirsch, op. cit., note 1 above, p. 142 fn.; Prinzing, op. cit., note 1 above, p. 198.

${ }^{36}$ Smallpox had been subject to mandatory notification in the provinces of Prussia since 1835. See Guttstadt, op. cit., note 12 above, p. 129. 


\section{Geographical Transmission of Smallpox in the Franco-Prussian War}

inoculation question) appeared in volume 13 (1873) of the Prussian Statistical Office's publication Zeitschrift des königlich Preussischen Statistischen Bureaus. ${ }^{37}$

As described earlier, the outbreak of smallpox in wartime Prussia was to spread widely among French POWs and Prussian civilians. Accordingly, Table 2 is based on information abstracted from 'Die Pocken-Epidemie in Preussen' and summarizes the progress of the epidemic in the two functionally discrete-but geographically concordant-settlement systems to which these populations were attached. We consider each settlement system in turn.

(1) Settlement system I: military (POW camps and related facilities). For many French soldiers who were captured during the Franco-Prussian War, transfer from the theatre of operations was followed by incarceration in an interconnected system of Prussian POW camps. Although the size and extent of this camp system was to vary over the course of the hostilities, Guttstadt identified a total of 78 locations which, at some stage during the war, formed the site of POW camps and other POW-related facilities (including military hospitals and lazarets). Unfortunately, however, the demographic and/or disease records for some of these locations are fragmentary. For the purposes of the present paper, therefore, we restrict our analysis to POW facilities at a sample of 56 locations for which complete data records are available. These 56 locations are given in Table 2, along with information on (i) the maximum strength of the associated POW population, and (ii) the time, in weeks, from the start of the war to the first appearance of smallpox in that population.

(2) Settlement system II: civilian (urban centres). Each of the 56 locations of POW camps and related facilities was attached to an urban centre (town or city). For these urban centres, Table 2 gives (i) the size of the civil population as registered under the post-war census of 1871, and (ii) the time, in weeks, from the start of the war to the first appearance of smallpox in the civil population.

For each settlement system, the time to the first appearance of smallpox at a given location has been formed in Table 2 by coding the first week of the war (calendar week ending 23 July 1870 ) as week 1 , with subsequent weeks numbered sequentially up to, and including, the week of the ratification of the Treaty of Frankfurt (coded week 45, ending 27 May 1871). Finally, for reference, Table 2 also indicates the calendar month in which smallpox first appeared in the POW and civil populations at a given location. Unless stated otherwise, the information in Table 2 forms the basis of all subsequent analysis.

\section{Diffusion Processes}

Accounts of the spread of an infectious disease in a settlement system usually recognize three main types of diffusion process. A contagious process describes the situation in which the disease moves from its centre of introduction to its physically nearest neighbouring centres. These, in their turn, transmit the disease to their

\footnotetext{
${ }^{37}$ Guttstadt, op. cit., note 12 above. For an English-language overview of the contents of
}

Guttstadt's original study, see Prinzing, op. cit., note 1 above, pp. 214-51 passim. 
Matthew Smallman-Raynor and Andrew D Cliff

Table 2

Smallpox in Prussia, July 1870-January 1871

\begin{tabular}{|c|c|c|c|c|}
\hline \multirow[t]{2}{*}{$\begin{array}{l}\text { Location } \\
\text { (town/city) }\end{array}$} & \multicolumn{2}{|c|}{$\begin{array}{l}\text { Settlement system I: } \\
\text { Military (POW camps) }\end{array}$} & \multicolumn{2}{|c|}{$\begin{array}{l}\text { Settlement system II: } \\
\text { Civilian (urban centres) }\end{array}$} \\
\hline & $\begin{array}{l}\text { Maximum } \\
\text { Population }\end{array}$ & $\begin{array}{l}\text { Time to first } \\
\text { appearance of } \\
\text { smallpox (weeks) }\end{array}$ & Population $^{2}$ & $\begin{array}{l}\text { Time to first } \\
\text { appearance of } \\
\text { smallpox (weeks) }\end{array}$ \\
\hline Aschersleben & 1,618 & 22 (Dec 1870) & 16,739 & 22 (Dec 1870) \\
\hline Aurich & 1,000 & 28 (Jan 1871) & 4,262 & Not known \\
\hline Bonn & 335 & $16($ Nov 1870$)$ & 26,020 & Not known \\
\hline Coblenz & 19,011 & $10(\operatorname{Sep} 1870)$ & 33,365 & 16 (Nov 1870) \\
\hline Colberg & 5,246 & 18 (Nov 1870$)$ & 13,130 & $25(\operatorname{Jan} 1871)$ \\
\hline Cologne & 16,774 & 7 (Sep 1870) & 129,230 & 9 (Sep 1870) \\
\hline Cörlin & 798 & 22 (Dec 1870) & 2,949 & Not known \\
\hline Cosel & 5,233 & 10 (Sep 1870) & 4,517 & Not known \\
\hline Cottbus & 142 & 19 (Nov 1870) & 18,916 & Not known \\
\hline Cüstrin & 2,204 & 5 (Aug 1870) & 10,122 & 24 (Dec 1870) \\
\hline Danzig & 9,189 & $7(\text { Aug } 1870)^{3}$ & 89,121 & 9 (Sep 1870) \\
\hline Düsseldorf & 981 & 5 (Aug 1870) & 69,351 & 14 (Oct 1870) \\
\hline Erfurt & 12,400 & $9(\operatorname{Sep} 1870)$ & 43,616 & 22 (Dec 1870) \\
\hline Falkenberg & 3,983 & 27 (Jan 1871) & 1,960 & Not known \\
\hline Frankfurt a. $\mathrm{O}$. & 756 & 17 (Nov 1870) & 43,211 & 27 (Jan 1871) \\
\hline Glatz & 3,084 & 17 (Nov 1870) & 11,541 & 31 (Feb 1871) \\
\hline Glogau & 13,921 & $9(\operatorname{Sep} 1870)$ & 18,265 & 12 (Oct 1870$)$ \\
\hline Görlitz & 326 & 24 (Dec 1870) & 42,224 & 27 (Jan 1871) \\
\hline Graudenz & 1,437 & 7 (Aug 1870) & 15,559 & Not known \\
\hline Halberstadt & 619 & $28(\operatorname{Jan} 1871)$ & 25,421 & 31 (Feb 1871) \\
\hline Hanover & 2,299 & 14 (Oct 1870) & 87,641 & Not known \\
\hline Jüterbogk & 5,002 & 27 (Jan 1871) & 6,673 & Not known \\
\hline Königsberg & 7,324 & 5 (Aug 1870) & 112,123 & 7 (Aug 1870) \\
\hline Landsberg & 133 & 18 (Nov 1870) & 18,531 & 19 (Nov 1870) \\
\hline Magdeburg & 25,450 & $9(\operatorname{Sep} 1870)$ & 114,552 & 18 (Nov 1870) \\
\hline Minden & 6,171 & 11 (Oct 1870) & 16,593 & 16 (Nov 1870) \\
\hline Mühlhausen & 1,065 & 21 (Dec 1870) & 19,516 & 29 (Feb 1871) \\
\hline Münster & 3,009 & 29 (Feb 1871) & 24,815 & 31 (Feb 1871) \\
\hline Neisse & 17,801 & $11(\operatorname{Sep} 1870)$ & 19,376 & Not known \\
\hline Oppeln & 1,227 & 27 (Jan 1871) & 11,879 & $27(\operatorname{Jan} 1871)$ \\
\hline Papenburg & 993 & 20 (Nov 1870) & 6,077 & Not known \\
\hline Pillau & 408 & 29 (Jan 1871) & 2,909 & Not known \\
\hline Posen & 10,303 & $9(\operatorname{Sep} 1870)^{3}$ & 56,464 & 9 (Sep 1870) \\
\hline Quedlinburg & 927 & 20 (Nov 1870) & 16,402 & 18 (Nov 1870) \\
\hline Ratibor & 834 & 22 (Dec 1870) & 15,323 & Not known \\
\hline Rendsburg & 2,592 & 19 (Nov 1870) & 11,514 & 24 (Dec 1870) \\
\hline Schievelbein & 603 & $28(\operatorname{Jan} 1871)$ & 5,514 & 32 (Feb 1871) \\
\hline
\end{tabular}


Table 2-continued

\begin{tabular}{|c|c|c|c|c|}
\hline \multirow[t]{2}{*}{$\begin{array}{l}\text { Location } \\
\text { (town/city) }\end{array}$} & \multicolumn{2}{|c|}{$\begin{array}{l}\text { Settlement system I: } \\
\text { Military (POW camps) }\end{array}$} & \multicolumn{2}{|c|}{$\begin{array}{l}\text { Settlement system II: } \\
\text { Civilian (urban centres) }\end{array}$} \\
\hline & $\begin{array}{l}\text { Maximum } \\
\text { Population }\end{array}$ & $\begin{array}{l}\text { Time to first } \\
\text { appearance of } \\
\text { smallpox (weeks) }\end{array}$ & Population $^{2}$ & $\begin{array}{l}\text { Time to first } \\
\text { appearance of } \\
\text { smallpox (weeks) }\end{array}$ \\
\hline Schleswig & 1,571 & 22 (Dec 1870) & 13,821 & 24 (Dec 1870) \\
\hline Schneidemühl & $940^{3}$ & $29(\operatorname{Jan} 1871)$ & 7,536 & 27 (Jan 1870) \\
\hline Schweidnitz & 2,621 & 29 (Feb 1871) & 16,998 & 35 (Mar 1871) \\
\hline Spandau & 6,855 & $10($ Sep 1870) & 19,013 & Not known \\
\hline Stade & 2,284 & $28(\mathrm{Jan} 1871)$ & 8,693 & Not known \\
\hline Stendal & 51 & 27 (Jan 1871) & 9,938 & 27 (Jan 1871) \\
\hline Stettin & $21,000^{3}$ & $10(\operatorname{Sep} 1870)$ & 76,149 & 22 (Dec 1870) \\
\hline Stolp & 1,376 & 29 (Feb 1871) & 16,280 & Not known \\
\hline Stralsrund & 2,991 & 21 (Dec 1870) & 26,731 & $25(\operatorname{Jan} 1871)$ \\
\hline Swinemünde & 1,150 & $25(\operatorname{Jan} 1871)$ & 6,850 & Not known \\
\hline Tangermünde & 798 & 29 (Jan 1871) & 4,855 & Not known \\
\hline Thorn & 2,601 & 6 (Aug 1870) & 16,620 & Not known \\
\hline Torgau & 9,359 & 12 (Oct 1870) & 10,867 & 18 (Nov 1870) \\
\hline Trier & 312 & 16 (Nov 1870$)$ & 31,842 & Not known \\
\hline Uckermünde & 749 & $28(\operatorname{Jan} 1871)$ & 3,758 & Not known \\
\hline Weissenfels & 148 & 29 (Feb 1871) & 15,443 & 31 (Feb 1871) \\
\hline Wesel & 18,099 & 10 (Sep 1870) & 18,519 & 18 (Nov 1870) \\
\hline Wittenberg & 9,753 & $8($ Sep 1870) & 11,567 & 12 (Oct 1870) \\
\hline Wohlau & 396 & $28(\mathrm{Jan} 1871)$ & 2,863 & Not known \\
\hline
\end{tabular}

${ }^{1}$ Time, in weeks, from the start of the Franco-Prussian War (week ending 23 July 1870, coded week 1) to the first appearance of smallpox. For reference, the calendar month in which smallpox first appeared is given in parentheses. ${ }^{2}$ Registered population, 1871 census. ${ }^{3}$ Additional data from Friedrich Prinzing, Epidemics resulting from wars, Oxford, Clarendon Press, 1916, pp. 215-16.

Source: data abstracted from Albert Guttstadt, 'Die Pocken-Epidemie in Preussen, insbesondere in Berlin 1870/72', Zeitschrift des königlich Preussischen Statistischen Bureaus, 1873, 13: 116-58.

geographically nearest neighbours, and so on. In this way, the disease spreads in a wave-like manner outwards from its point of introduction. Alternatively, a hierarchical process describes the situation in which the disease moves progressively through the settlement size hierarchy. Typically, the initial point of introduction of a disease is the most populous settlement. Then, settlements next in size follow, and so on, through to the smallest settlements. Finally, a mixed process describes the situation in which the spread pattern contains components of both contagious and hierarchical diffusion. ${ }^{38}$

${ }^{38}$ Cliff and Haggett, op. cit., note 14 above. 


\section{Matthew Smallman-Raynor and Andrew D Cliff}

A number of methods have been developed for the identification and analysis of these diffusion processes. In this paper, we apply one such technique (multiple regression analysis) to the data in Table 2 . We begin with a consideration of the processes by which smallpox spread in the military system of POW camps and related facilities (settlement system I). We then turn to the spread of smallpox in the civil system of urban centres (settlement system II).

\section{Diffusion of Smallpox, I: French POWs}

For the period of the Franco-Prussian War (July 1870 to January 1871) and its immediate aftermath, Figure 2 is based on the information in Table 2 and maps the time-ordered sequence of appearance of smallpox in French POWs detained at 56 locations in Prussia. Shaded circles identify those locations in which smallpox first appeared in the prisoner population in August 1870 (Figure 2A), September 1870 (Figure 2B), October and November 1870 (Figure 2C), and December 1870 to February 1871 (Figure 2D); on each map, the unshaded circles identify camps which were infected in prior time periods. Finally, to assist in the interpretation of Figure 2 , the area of each circle has been drawn proportional to the (maximum) strength of the POW population.

(1) August 1870 (Figure 2A). In August 1870-within weeks of the outbreak of war and with France consumed by a severe epidemic of haemorrhagic smallpox - cases of the disease began to appear among French soldiers in the newly-established POW camps of Prussia. As Figure 2A indicates, this initial phase of the epidemic was centred on eastern Prussia, where the earliest transports of French prisoners had begun to arrive on 7 August. ${ }^{39}$ Eight days later, on 15 August, the first case of

Figure 2 (opposite): Spread of smallpox with French Prisoners of War (POWs) in Prussia, 1870-71. The maps plot the calendar month in which smallpox first appeared in French prisoners at each of 56 locations. (A) August 1870. (B) September 1870. (C) October and November 1870. (D) December 1870-February 1871. Shaded circles identify locations first infected during the time period covered by the map; unshaded circles mark locations infected in prior time periods. Circles are drawn proportional to the maximum prisoner population at each location. Numerical codes identify the following locations: 1, Düsseldorf; 2, Königsberg; 3, Cüstrin; 4, Thorn; 5, Danzig; 6, Graudenz; 7, Cologne; 8, Wittenberg; 9, Erfurt; 10, Glogau; 11, Magdeburg; 12, Posen; 13, Coblenz; 14, Cosel; 15, Spandau; 16, Stettin; 17, Wesel; 18, Neisse; 19, Minden; 20, Torgau; 21, Hanover; 22, Bonn; 23, Trier; 24, Frankfurt an der Oder; 25, Glatz; 26, Colberg; 27, Landsberg; 28, Cottbus; 29, Rendsburg; 30, Papenburg; 31, Quedlinburg; 32, Mülhausen; 33, Stralsrund; 34, Aschersleben; 35, Cörlin; 36, Ratibor; 37, Schleswig; 38, Görlitz; 39, Swinemünde; 40, Falkenberg; 41, Jüterbogk; 42, Oppeln; 43, Stendal; 44, Aurich; 45, Halberstadt; 46, Schievelbein; 47, Stade; 48, Uckermünde; 49, Wohlau; 50, Münster; 51, Pillau; 52, Schneidemühl; 53, Schweidnitz; 54, Stolp; 55, Tangermünde; 56, Weissenfels.

${ }^{39}$ Guttstadt, op. cit., note 12 above, p. 140. 

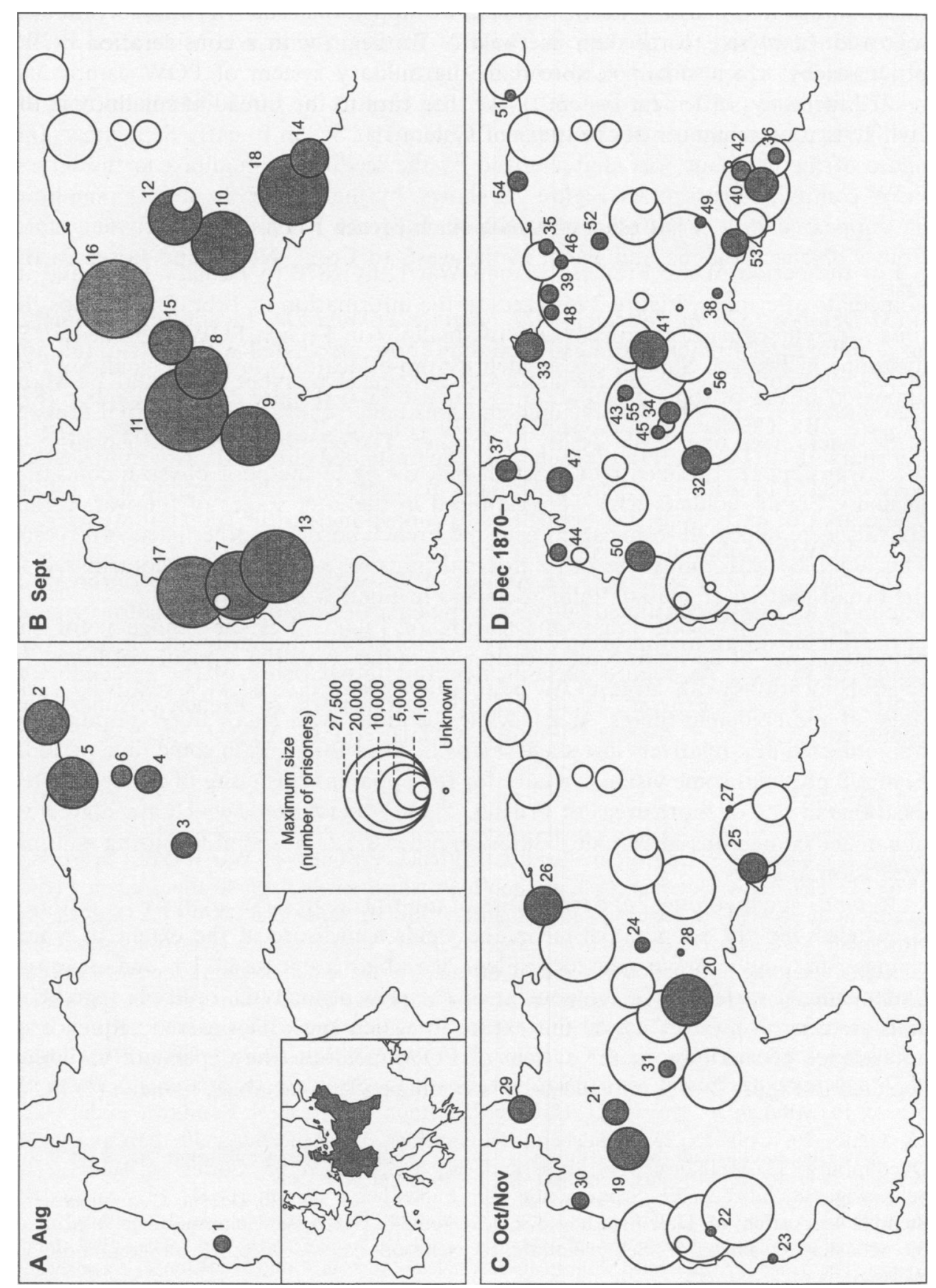


\section{Matthew Smallman-Raynor and Andrew D Cliff}

smallpox appeared in the POW camp at Königsberg, ${ }^{40}$ with the disease manifesting in the camps at Cüstrin, Danzig, Graudenz and Thorn in the days and weeks that followed. Elsewhere, to the extreme west of Prussia, the arrival of infected POWs at Düsseldorf can also be traced to mid-August. ${ }^{41}$

(2) September 1870 (Figure 2B). With the capture of Louis-Napoleon and the 104,000-strong remnants of the army of Châlons at Sedan in early September, this phase of the epidemic was characterized by the seeding of smallpox in the largest POW camps of Prussia. As Figure 2B shows, by the end of the month, smallpox had appeared in a series of camps that spanned the whole of the Prussian state, from Coblenz, Cologne and Wesel in the west, to Cosel, Neisse and Posen in the east.

(3) October 1870 to February 1871 (Figures $2 C$ and D). In addition to further large influxes of French prisoners, including those associated with the capitulation of Metz (October 1870) and the battles of Orléans (December 1870) and Le Mans (January 1871), this phase of the epidemic was underpinned by the internal transfer of prisoners from one POW facility to another. The circumstances that gave rise to these transfers are outlined by Guttstadt but, owing to the poor physical condition of many French soldiers who were captured in the later stages of the war, earlier arrivals were relocated from camps near the French border to other parts of Prussia. This, coupled with numerous other internal transfers of prisoners, ${ }^{42}$ contributed to the broad pattern of spatial "infill" depicted in Figures $2 \mathrm{C}$ and D.

Spread processes. One important feature of Figure 2 is the tendency for the population size of newly-infected locations to reduce over the sequence of maps. In general, locations with large POW populations were infected at a relatively early stage of the epidemic (maps A, B), while locations with small POW populations were infected at a relatively late stage (maps C, D). Moreover, in some time periods, Figure 2 provides some visual evidence for the apparent clustering of newly-infected locations in one or more areas of Prussia. These observations, which are suggestive of a mixed contagious-hierarchical diffusion process, can be quantified using multiple regression analysis.

Method. The theoretical underpinnings of multiple regression analysis are outlined elsewhere ${ }^{43}$ but, in essence, the technique yields a measure of the extent to which changes in one variable (the dependent variable) are caused by one or more (independent) variables. In the context of the present analysis, multiple regression analysis can be used to assess the extent to which the time-ordered sequence of appearance of smallpox in the system of POW facilities (the dependent variable), depicted in Figure 2, was influenced by two independent variables, namely: (1) POW

\footnotetext{
${ }^{40}$ According to Guttstadt (op. cit., note 12 above, pp. 140-2), one of the first documented cases of smallpox in the POW population was Zuave Hubert, an unvaccinated French soldier who arrived at Königsberg in the second week of August. The patient first presented with smallpox on 15 August; he died seven days later, on 22 August.

${ }^{41}$ Guttstadt, op. cit., note 12 above, pp. 140-2.
}

\footnotetext{
${ }^{42}$ For examples, see Prinzing, op. cit., note 1 above, pp. 228, 243.

${ }^{43}$ See, for example, Douglas C Montgomery and Elizabeth A Peck, Introduction to linear regression analysis, New York, Wiley, 1992; John Neter, Michael Kutner, Christopher Nachtsheim and William Wasserman, Applied linear regression models, 3rd ed., Chicago, Irwin, 1996.
} 


\section{Geographical Transmission of Smallpox in the Franco-Prussian War}

population size, representing the hierarchical component in the spread process; and (2) geographical distance from the location in which smallpox first appeared in the POW population, representing the contagious component. Thus, with reference to the time-based information in Table 2, the schematic regression model (1) was postulated:

\section{Week of appearance = function of (1) POW camp population, (2) distance of camp from place of first report in the POW population. ${ }^{44}$}

The model in equation (1) was fitted to the 56 locations of POW camps and related facilities in Table 2. Because the reported origin of the epidemic was at four geographically disparate localities (Berlin, ${ }^{45}$ Cüstrin, Düsseldorf and Königsberg) in week 5 of the war (week ending Saturday 20 August 1870), the distance variable (2) in equation (1) was estimated as the minimum distance between each camp and each of the four index locations. One potential complication in the regression procedure is possible co-linearity between population size and distance. In particular, a decrease in POW population size with increasing distance would hinder separation of the contagious and hierarchical components in the model. ${ }^{46}$

Results. The application of regression analysis to the diffusion problem is illustrated graphically in Figure 3. The white circles in Figure 3A plot, on the horizontal axis, the time to infection from the start of the war (week 1) to the appearance of smallpox in French prisoners against, on the vertical axis, the straightline distance from the nearest index location (Berlin, Cüstrin, Düsseldorf and Königsberg). ${ }^{47}$

\footnotetext{
${ }^{44}$ Mathematically, this relationship may be written as follows. Let $t_{p i}$ denote the week of the war in which smallpox first appeared in the POW population $p$ at locality $i$. Then the model $t_{p i}=$ $b_{0}+b_{1} \log \left(P_{p i}+1\right)+b_{2} \log \left(d_{p i}+1\right)+e_{i}$ was postulated. Here, $\boldsymbol{P}_{p i}$ is the maximum size of the prisoner population at location $i, d_{p i}$ is the straight-line distance (in kilometres) of that location from the location(s) in which smallpox was first reported in the POW population and $e_{i}$ is an error term. For the epidemic under consideration, the independent variables, $\boldsymbol{P}_{p i}$ and $d_{p i}$, have a logarithmic relationship with $t_{p i}$; the logarithmic transformations in equation (1) serve to linearize these, while the addition of 1 avoids the computational problem of zero values when taking logs. The model was fitted using stepwise regression techniques. The stepwise procedure enters the independent variables, $\log \left(P_{p i}+1\right)$ and $\log \left(d_{p i}+1\right)$, into the regression model in reducing order of importance as defined by the level of variance explained in the dependent variable, $t_{p i}$. In this manner, the most important explanatory
}

variable is entered in step 1 of the model. For an example of the application of multiple regression techniques to the analysis of epidemiological diffusion processes, see Andrew Cliff, Peter Haggett, Keith Ord and G Versey, Spatial diffusion: an historical geography of epidemics in an island community, Cambridge University Press, 1981, pp. 27-32.

${ }^{45}$ According to Guttstadt (op. cit., note 12 above, p. 141), smallpox first appeared in the POW population of Berlin on 20 August 1870. Although Berlin has been omitted from Table 2 due to lack of demographically-related information, the role of this city as an index location is recognized by its inclusion in the computation of $d_{p i}$.

${ }^{46}$ To check for this problem, Pearson's $r$ correlation coefficient was used to assess the level of correlation between the independent variables.

${ }^{47}$ To assist in the interpretation of Figure 3A, three extreme outliers (the index locations of Cüstrin, Düsseldorf and Königsberg) have been omitted from the scatter plot. 


\section{Matthew Smallman-Raynor and Andrew D Cliff}

Similarly, the white circles in Figure $3 \mathrm{~B}$ plot time to infection against POW population size. Superimposed on each scatter plot is a best fit linear regression line (marked "prisoners").

A striking feature of Figure 3 is the negative association between population size and time to infection (chart B). This implies that large POW populations were infected at an early stage of the epidemic, while small POW populations were infected at a relatively late stage. It is consistent with the hierarchical effect identified in Figure 2. However, only weak evidence exists for the operation of a contagious component (chart A). Under this process, a direct (positive) relationship between the distance of camps from the point of initial smallpox introduction and week of outbreak would be expected. The near-horizontal regression line in Figure 3A reflects the low association.

Models 1 and 2 in Table 3 examine the spread process using the framework of the regression model defined in equation (1). For each model, the table gives a qualitative interpretation of the results. The statistical results upon which this table is based appear in the appendix to the paper (see p. 264).

Model 1, which relates to the entire set of 56 locations, shows that time to infection is negatively associated with the population variable and positively associated with the distance variable; the insignificant correlation between the independent variables implies that the modelling procedure was successful in separating the hierarchical and contagious components. As would be expected from the simple regressions in Figure 3, however, the dominant importance of the population variable is demonstrated by its entry in step 1 of the model.

Although model 1 implies the operation of a mixed diffusion process with a dominant hierarchical component, three locations (the index locations of Cüstrin, Düsseldorf and Königsberg) serve as extreme outliers which heavily influence the statistical parameters of the model. ${ }^{48}$ Consequently, model 2 repeats the analysis of model 1 but with the three outliers omitted. Modified in this way, the importance of the population variable to the spread process is underscored by its entry in step 1 of model 2; in addition, the distance variable does not make a statistically significant contribution.

Figure 3 (opposite): Diffusion of smallpox in Prussia during the Franco-Prussian War, 1870-71. Graphs plot the week of the war in which smallpox was first reported in French POWs and Prussian civilians at sample locations in relation to their distance from the points of introduction of smallpox in the POW population (chart A) and POW population sizes (chart B). The horizontal axes have been formed by coding the first calendar week of the war (week ending 23 July 1870) as week 1, with subsequent weeks coded sequentially thereafter. Superimposed on each set of data points is a trend line fitted to the data by ordinary least squares. Note that the vertical axes have been drawn on a logarithmic scale to linearize relationships.

\footnotetext{
${ }^{48}$ For the purposes of the present analysis, extreme outliers were identified by (i) visual inspection of time-distance and time-population plots coupled with (ii) examination of
} 

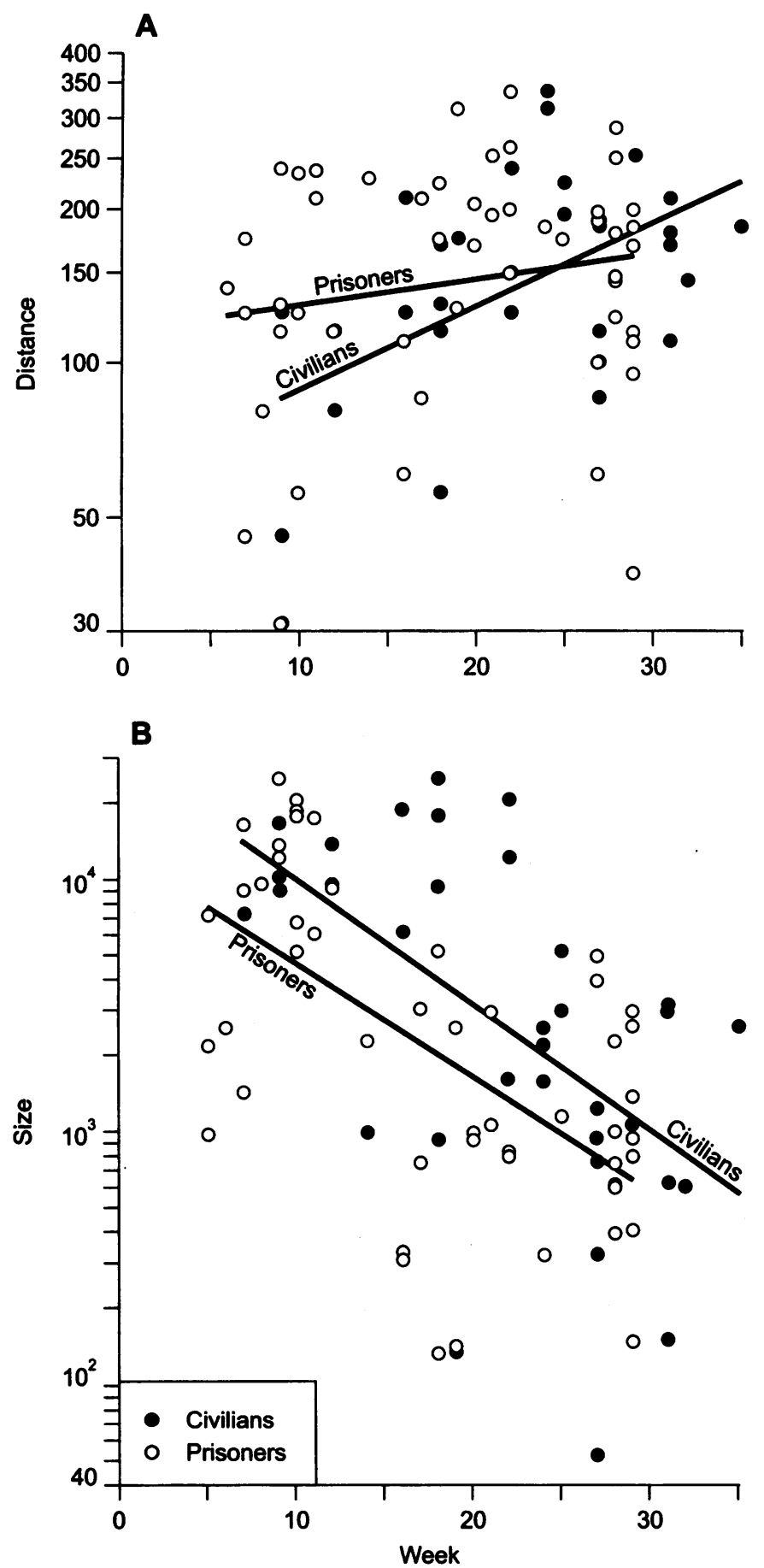

Figure 3 
Table 3

Qualitative presentation of results of stepwise multiple regression analysis to identify diffusion processes for smallpox in Prussia, 1870-71

\begin{tabular}{|c|c|c|c|c|c|}
\hline \multirow[t]{2}{*}{ Model } & \multirow[t]{2}{*}{$\begin{array}{l}\text { Dependent } \\
\text { variable }\end{array}$} & \multirow[t]{2}{*}{$\begin{array}{l}\text { Number of } \\
\text { observations }\end{array}$} & \multicolumn{2}{|c|}{$\begin{array}{l}\text { Relationship }(+I-) \\
\text { with dependent } \\
\text { variable }\end{array}$} & \multirow{2}{*}{$\begin{array}{l}\text { Percentage Process } \\
\text { of variation } \\
\text { in time to } \\
\text { smallpox } \\
\text { appearance } \\
\text { explained }\end{array}$} \\
\hline & & & $\begin{array}{l}\text { Most } \\
\text { important } \\
\text { (step 1) }\end{array}$ & $\begin{array}{l}\text { Least } \\
\text { important } \\
\text { (step 2) }\end{array}$ & \\
\hline
\end{tabular}

\section{Settlement system I: POW camps}

$1 \quad$ Time to smallpox appearance in

2 French POWs

56

$53^{1}$

Settlement system II: urban centres

$\begin{array}{ll}\text { Camp } & \text { Distance } \\ \text { size } & \text { from } \\ & \text { smallpox } \\ & \text { origin }\end{array}$

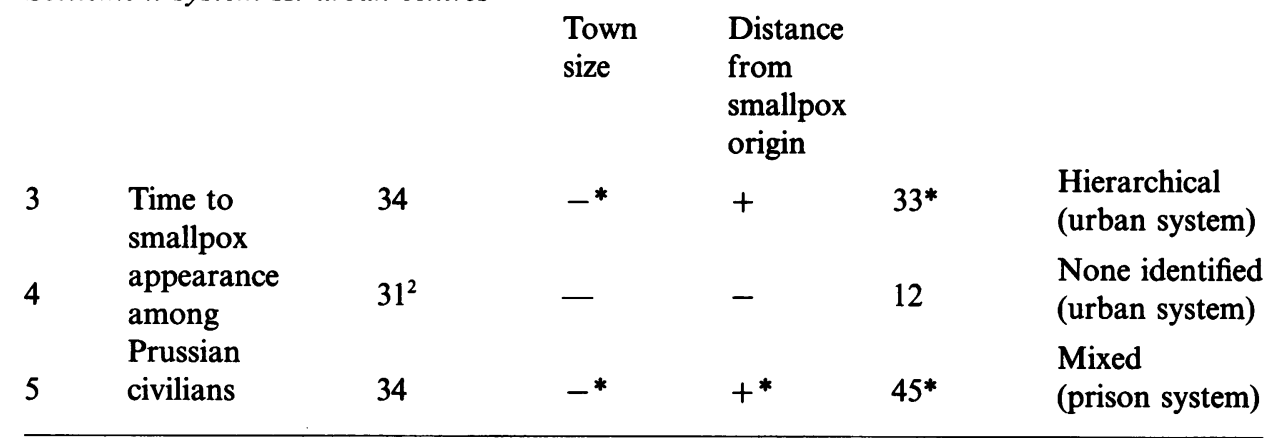

Notes:

${ }^{1}$ Cüstrin, Düsseldorf and Königsberg omitted as extreme outliers. ${ }^{2}$ Cologne, Danzig and Königsberg omitted as extreme outliers.

Full definition of dependent variables

1. Time (in weeks) from the start of the war to the first appearance of smallpox in French POWs.

2. Time (in weeks) from the start of the war to the first appearance of smallpox in Prussian civilians.

Full definition of independent variables

1. In settlement system I (POW camps). (a) Camp size = maximum POW population size; (b) Distance from smallpox origin = distance (in kilometres) to a camp from the location(s) at which smallpox was first reported in the French POW population.

2. In settlement system II (urban centres). For models 3-4, (a) Town size = civil population size in 1871 Census; (b) Distance from smallpox origin = distance (in kilometres) of town from the location(s) at which smallpox was first reported in the Prussian civil population. For model 5, as models 1-2.

+ Positive relationship between variables.

- Negative relationship between variables.

* Statistically significant. Less than five per cent likelihood of relationship occurring by chance. 


\section{Geographical Transmission of Smallpox in the Franco-Prussian War}

Interpretation. When modified for the effects of outliers, the results are consistent with a simple model of geographical transmission in which smallpox spread hierarchically through the system of POW camps and related facilities. It is important to note, however, that the operation of this process was linked closely to the development of the POW population size hierarchy. As the war progressed, the system of POW facilities evolved to include locations with increasingly smaller holdings of prisoners. ${ }^{49}$ Some of these smaller holdings are known to have been infected as a result of the internal transfer of prisoners from larger POW populations ${ }^{50}$ and are therefore consistent with the operation of a strict hierarchical process. However, in the absence of further information, a potential confounding effect (namely, the infection of increasingly smaller POW populations as a result of disease re-importations by later arrivals of prisoners from the French theatre) cannot be excluded.

\section{Diffusion of Smallpox, II: Prussian Civilians}

To examine the mechanism by which smallpox spread in the civil system of urban centres, we extend our application of multiple regression to the civilian-based information in Table 2. The time-ordered sequence of appearance of smallpox in the civil population is modelled as a function of the structure (population size and geographical position) of settlements in:

(i) the civil system of urban centres. This provides an intra-system examination of diffusion processes for the civil population;

(ii) the military system of POW camps and related facilities. This model represents an inter-system examination of diffusion processes from the POW to the civil population.

The rationale that underpins (i) and (ii) is outlined below. We preface our examination with a brief note on the data analysed. Although Table 2 identifies 56 locations for which information on the date of first appearance of smallpox in the POW population is available, the equivalent information for the civil population is limited to 34 locations, and these form the basis of our analysis.

(i) Urban centres: intra-system diffusion processes. Studies of the spread of infectious diseases in civil populations usually identify a close association between diffusion process and the structure (population size and/or geographical position) of settlements in the urban system. Paralleling equation (1) we may set up another schematic regression equation (2) for this effect, namely:

\footnotetext{
${ }^{49}$ Based on a sample of 40 locations in Table 2 , and for which information is provided by Guttstadt (op. cit., note 12 above), a highly significant and negative association $(r=-0.60$; $t=-4.68 ; p<0.05$ in a one-tailed test) exists between (i) the time (measured in weeks from the beginning of the war) of arrival of the first POWs
}

and (ii) the maximum size of the POW population.

${ }^{50}$ Examples of the spread of smallpox with the internal transfer of French POWs are given in: Guttstadt, op. cit., note 12 above, pp. 140-50; Prinzing, op. cit., note 1 above, pp. 214-51. 
Week of appearance of smallpox in civil population of a given location = function of (1) population of location in 1871 census, and (2) straight-line distance (in kilometres) of location from the place where smallpox was first reported in the civil population. ${ }^{51}$

The regression model in equation (2) was fitted to the 34 civil locations in Table 2. As this table shows, the first evidence of smallpox in the civil population can be traced to a single location (Königsberg) in week 7 of the war (week ending 3 September 1870). Accordingly, the distance variable in equation (2) was measured as the distance between each locality and Königsberg.

The results are summarized as models 3 and 4 in Table 3. Model 3, which relates to the entire set of 34 locations, shows that time to infection is negatively associated with population, while distance fails to make a statistically significant contribution. However, as model 4 shows, the omission of three outliers (Cologne, Danzig and Königsberg) yields a rather different result. ${ }^{52}$ Both independent variables are statistically insignificant, indicating that the spread of smallpox in the civil population was detached from the structural parameters (population size and geographical position) of settlements in the urban system.

(ii) POW camps: inter-system diffusion processes. When examined with reference to the 34 locations for which complete information is available, one important feature of Table 2 is the tendency for the first appearance of smallpox in the civil population to lag the POW population by several weeks or more. So, on average, the time to the first appearance of smallpox in a locality varied from 16.8 weeks for French POWs to 21.7 weeks for Prussian civilians. Here, the (16.8 weeks to 21.7 weeks) difference in timing is equivalent to a lag of 34 days, or approximately three generations of the smallpox virus. ${ }^{53}$

This lag effect is consistent with a simple model of epidemic transmission in which, during the Franco-Prussian War and its immediate aftermath, POW camps and related facilities acted as the epidemic seeds from which smallpox spread to the local civil population. ${ }^{54}$ Supported by empirical evidence for the transmission of smallpox

\footnotetext{
${ }^{51}$ Denote the week of the war in which smallpox first appeared in the civil population $c$ at location $i$ as $t_{c i}$. Then, equation (2) may be written as $t_{c i}=b_{0}+b_{1} \log \left(P_{c i}+1\right)+b_{2}$ $\log \left(d_{c i}+1\right)+e_{i}$, where $P_{c i}$ is the size of the civil population at location $i$ given in the census of 1871 , and $d_{c i}$ is the straight-line distance (in kilometres) of location $i$ from the location in which smallpox was first reported in the civil population. As in equation (1), the logarithmic transformations serve to linearize the relationships between the independent variables, $P_{c i}$ and $d_{c i}$, and the dependent variable, $t_{c i}$.
} 


\section{Geographical Transmission of Smallpox in the Franco-Prussian War}

from prisoner to civilian populations, ${ }^{55}$ our model implies that the spread of the disease in the civil settlement system was pinned to the structure of the temporary and makeshift system of POW camps and related facilities.

Graphical analysis. The inter-system diffusion effect is examined graphically in Figure 3. Here, the black circles in Figure 3A plot, on the horizontal axis, the time to infection from the start of the war (week 1) to the appearance of smallpox in Prussian civilians against, on the vertical axis, the straight-line distance from the location(s) in which smallpox was first reported in French prisoners. Similarly, the black circles in Figure 3B plot time to infection against the POW population size.

Figure 3B indicates that the negative association shown earlier to exist between POW population size and time to infection (lower regression line) is mimicked by the civil population (upper regression line). Such a pattern accords with the operation of a hierarchical component in the diffusion process for both prisoners and civilians, although the time lag between the first appearance of the disease in the two populations (earlier among POWs) is underscored by the relative position of the regression lines. In contrast, Figure $3 \mathrm{~A}$ shows that a positive association between distance and time to infection is more pronounced for civilians than for prisoners. This finding suggests that a spatially contagious component may well have contributed to the diffusion of smallpox in the civil population of Prussia.

Multiple regression analysis. To examine the inter-system diffusion effect, the week of the war in which smallpox first appeared in the civil population was substituted as the dependent variable in equation (1); the independent variables were unchanged from the original model. The model was then fitted using stepwise regression to the 34 locations for which the time of first appearance of smallpox in the civilian population was known.

The results obtained are summarized as model 5 in Table 3. The model confirms that time to infection for the civil population is negatively associated with POW population size and positively associated with POW distance. The relative importance of the population variable is indicated by its entry in step 1 of the fitting procedure, while the statistically insignificant correlation between the independent variables indicates that the modelling procedure was successful in separating the hierarchical and contagious diffusion components.

Interpretation. Taken together, models 3-5 in Table 3 indicate that the spread of smallpox in the civil settlement system of Prussia was underpinned by a mixed contagious-hierarchical diffusion process with a dominant hierarchical component. Crucially, however, this process was detached from the basic structure (population size and geographical position) of settlements in the urban system (model 4). Rather,

\footnotetext{
${ }^{55}$ For a number of the locations in Table 2, Guttstadt traces the earliest cases of smallpox in the civilian population to individuals (guards, nurses and sick attendants, clergymen and laundry workers, among others) who had direct or indirect contact with the French POWs. Writing of the epidemics at Münster and Wittenberg, for example, Guttstadt notes that the first civilian cases of smallpox were clerics who
}

had ministered to the French POWs. Likewise, the earliest civilian cases at Stralsrund and Torgau were employees of the lazarets to which ailing prisoners had been assigned. Similar evidence can also be cited for Frankfurt an der Oder, Minden and Stettin, among other locations. See Guttstadt, op. cit., note 12 above, pp. 140-50; Prinzing, op. cit., note 1 above, pp. 214-51. 


\section{Matthew Smallman-Raynor and Andrew D Cliff}

the process was conditioned by the size and geographical arrangement of the temporary and makeshift system of POW camps and related facilities which had been fused onto the urban system (model 5). One plausible interpretation of these findings is that, during the course of the war, the large influx of French POWs was associated with a seeding of the epidemic which was so rapid and widespread that it overrode the processes by which the disease would ordinarily have spread in the civil settlement system of Prussia.

\section{Conclusions}

The enduring historical interest that attaches to the Prussian smallpox epidemic of 1870-72 rests with the intersection of war, disease transmission and demographic loss, the evolution of state legislative responses to smallpox control and the broader medicalization of the nascent German Empire. ${ }^{56}$ While the social and political ramifications of the $1870-72$ epidemic have been explored elsewhere, ${ }^{57}$ the present paper has added a geographical dimension to historical understanding by examining the processes that underpinned the spread of the epidemic in two functionally discrete settlement systems of Prussia (urban centres and POW camps/facilities) during the Franco-Prussian War, July 1870 to May 1871.

Two principal findings have emerged from our analysis. First, we have shown that smallpox spread through the military system of POW camps and related facilities of Prussia as a purely hierarchical diffusion process. Because the number of POWrelated facilities expanded during the course of the war to include locations with increasingly smaller holdings of prisoners, the hierarchical spread of smallpox was, itself, driven by the evolution of the POW settlement system. Second, we have shown that smallpox spread through the civil system of urban centres as a mixed diffusion process with a dominant hierarchical component. Contrary to expectation, however, this process was not structured according to the size and geographical position of settlements in the urban system. Rather, it was determined by the system of POW camps that had developed around the urban system during the course of the war.

When the present findings are set alongside the results of our earlier studies of war-related epidemics in late nineteenth-century $\mathrm{Cuba}^{58}$ and early twentieth century Philippine Islands, ${ }^{59}$ marked variations in the extent to which hostilities may affect on epidemic diffusion processes in civil settlement systems are evident. In particular, the population movements engendered by the Cuban Insurrection (1895-98) and the Philippine-American War (1899-1902) were found to be associated with a strengthening of the geographical corridors of epidemic transmission that would

\footnotetext{
${ }^{56}$ Prinzing, op. cit., note 1 above, pp. 282-5.

${ }^{57}$ See, for example, Richard J Evans, Death in Hamburg: society and politics in the cholera years, 1830-1910, Oxford, Clarendon Press, pp. 218-26; Huerkamp, op. cit., note 13 above; Hennock, op. cit., note 13 above.
} 


\section{Geographical Transmission of Smallpox in the Franco-Prussian War}

ordinarily be witnessed in peacetime. In contrast, the present analysis has demonstrated, for the first time, how the exigencies of war may result in a fundamental reconfiguration of epidemic diffusion processes in civil settlement systems.

While the paper has illustrated how the ideas of geographical diffusion can be used to enrich our understanding of the propagation of war epidemics, the analysis has also highlighted the historically important role of POW camps as institutions in the spread of smallpox. Although the role of other institutions (including hospitals and schools) in the localized amplification of smallpox outbreaks is generally well known, ${ }^{60}$ we have demonstrated how an inter-linked system of institutions may serve not only to intensify local disease activity, but also to structure the spatial course of a state-wide epidemic.

\footnotetext{
${ }^{60}$ For examples of the role of institutions in
} the spread of smallpox, see Fenner, et al., op. cit., note 5 above, pp. 201-2; Gwendoline $M$ Ayers, England's first state hospitals and the Metropolitan
Asylums Board, 1867-1930, London, Wellcome Institute of the History of Medicine, 1971, pp. 111-15. 


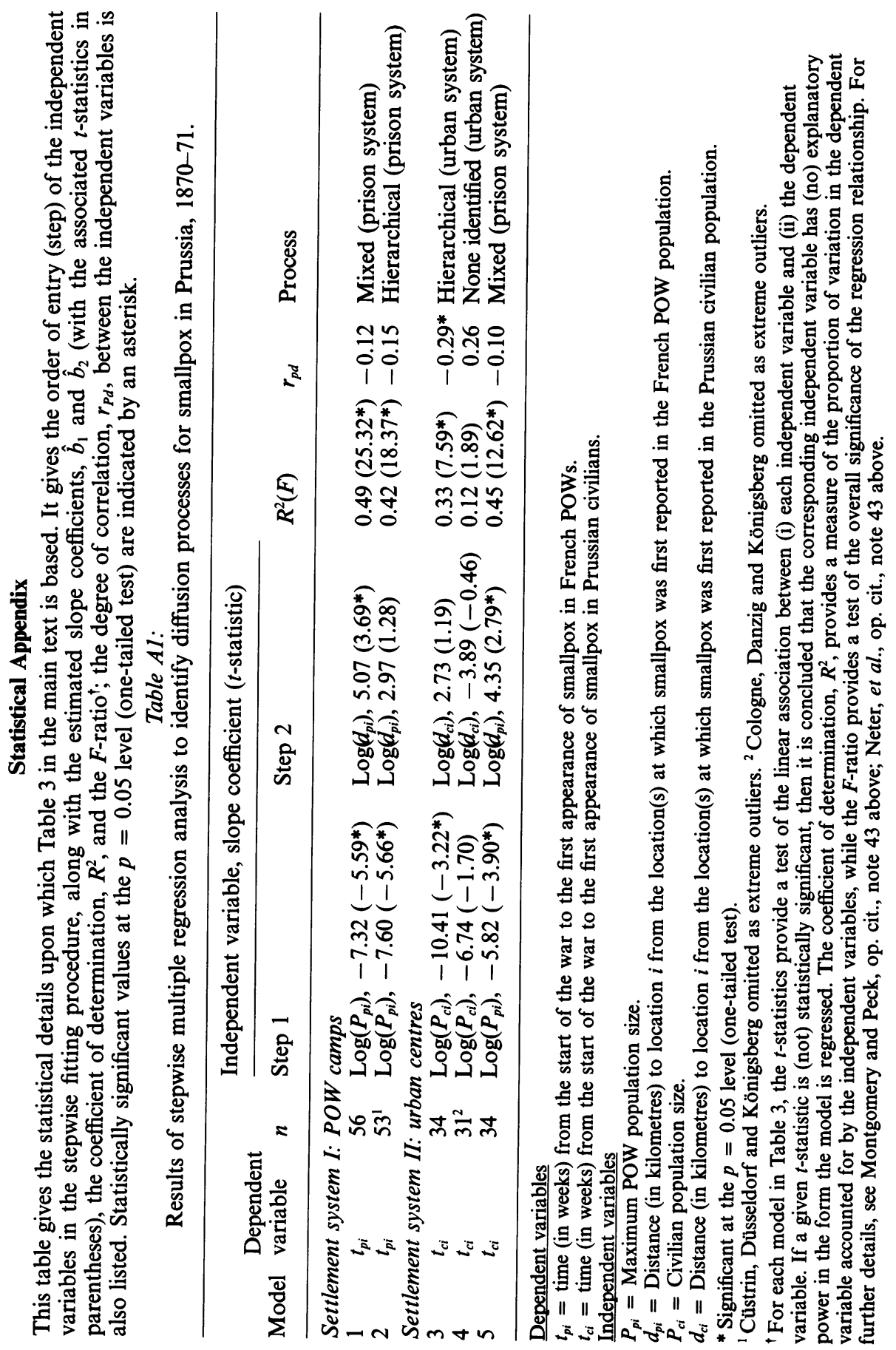

